\title{
Phytophthora x pelgrandis Causes Root and Collar Rot of Lavandula stoechas in Italy
}

Roberto Faedda, Santa Olga Cacciola, and Antonella Pane, Department of Agri-food and Environmental Systems Management, Plant Pathology Section, University of Catania, Catania, Italy; András Szigethy and József Bakonyi, Plant Protection Institute, Centre for Agricultural Research, Hungarian Academy of Sciences, Budapest, Hungary; Willem A. Man in't Veld, Plant Protection Service, Ministry of Economic Affairs, Agriculture and Innovation, Wageningen, the Netherlands; Patrizia Martini, Istituto Regionale per la Floricoltura, Sanremo, Italy; and Leonardo Schena and Gaetano Magnano di San Lio, Department of Agraria, University Mediterranea of Reggio Calabria, Italy

\begin{abstract}
Faedda, R., Cacciola, S. O., Pane, A., Szigethy, A., Bakonyi, J., Man in’t Veld, W. A., Martini, P., Schena, L., and Magnano di San Lio, G. 2013. Phytophthora $\times$ pelgrandis causes root and collar rot of Lavandula stoechas in Italy. Plant Dis. 97:1091-1096.

In 2007, Phytophthora isolates with atypical morphological and biological characteristics were found associated with root and collar rot of potted plants of Stoechas lavender (Lavandula stoechas) in an ornamental nursery in Italy. A polyphasic approach, including morphological and cultural observations, sequencing the ITS-rDNA region, the Pheca and the mitochondrial coxI genes, multiplex PCRs with primers specific for P. nicotianae or P. cactorum, as well as random amplified polymorphic DNA-polymerase chain reaction, was used to characterize these isolates. On the basis of morpho-cultural and molecular analyses, the isolates from Stoechas lavender were identified as Phytophthora $\times$ pelgrandis, a natural hybrid of $P$. nicotianae $\times P$. cactorum

previously reported in other European countries, the Americas, and Taiwan, as a pathogen of ornamentals and loquat plants. In pathogenicity tests using potted plants of Stoechas lavender, the $P . \times$ pelgrandis isolates, similarly to the parental species $P$. nicotianae, induced the symptoms observed on plants with natural infections and were reisolated only from artificially inoculated plants. Dispersal of $P . \times$ pelgrandis on this host could exacerbate the damage caused by Phytophthora root and collar rot, of which the main causal agent presently is P. nicotianae on lavender in Europe. Application of hygienic measures is important to reduce the proliferation and spread of the Phytophthora hybrids.
\end{abstract}

Lavender (Lavandula spp., family Lamiaceae) is widely cultivated in Italy as an ornamental and aromatic plant. It is estimated that lavender plants constitute about $30 \%$ of approximately 20 million potted aromatic plants produced each year in Liguria, the leading producing Italian region (28). In Italy, the most common disease of potted lavender in nurseries is Phytophthora root and collar rot. $P$. nicotianae is the prevalent species causing this disease. The pathogen was first reported on Lavandula spp. in Greece (33) and subsequently on English lavender (Lavandula angustifolia Mill.) in several other countries, including the United States (34), Italy (6,27), Spain (1), and Bulgaria (29). P. palmivora is another species quite common on lavender; it was recorded both on French lavender (L. dentata L.) in Spain (32) and English lavender in southern Italy (10) and Turkey (11). Another species infecting lavender is $P$. cinnamomi, which was found to be the causal agent of shoot and root rot of English lavender in greenhouse beds and container-grown nurseries in Poland (31). Hybrid isolates of $P$. nicotianae and $P$. cactorum, formally described as Phytophthora $\times$ pelgrandis W.F. Gerlach, Nirenberg \& Gräfenhan nothosp. nov. (30) from Pelargonium grandiflorum (Andr.) Willd., were also recovered from Lavandula sp. plants affected by root rot and basal stem necrosis in greenhouse in the Netherlands (4) and more recently in Hungary (35).

In October 2007, symptoms of leaf chlorosis, wilting associated with root and basal stem necrosis, and final collapse of the whole plant were observed on 4- to 6-month-old potted plants of Stoechas lavender (Lavandula stoechas L.) in an ornamental nursery in Liguria, northern Italy (lat. $44^{\circ} 3^{\prime} 43^{\prime \prime} \mathrm{N}$, long. $8^{\circ} 11^{\prime} 5^{\prime \prime} \mathrm{E}$ ). Disease

Corresponding author: Roberto Faedda, E-mail: rfaedda@unict.it

Accepted for publication 4 February 2013.

http://dx.doi.org/10.1094/PDIS-11-12-1035-RE

(C) 2013 The American Phytopathological Society incidence was about $30 \%$, with $15 \%$ dead plants in a nursery stock of 24,000 plants. Isolations from necrotic tissues of roots and basal stem consistently yielded Phytophthora colonies exhibiting morphological features resembling those reported for Phytophthora $\times$ pelgrandis. The aim of this study was to identify and characterize the atypical Phytophthora isolates from Stoechas lavender using a polyphasic approach, comprising morphological and cultural observations, sequencing of nuclear (internal transcribed spacer [ITS]-rDNA and Pheca) and mitochondrial (coxI) DNA regions as well as two species-specific multiplex polymerase chain reaction (PCR) and random amplified polymorphic DNA (RAPD)-PCR assays. In addition, pathogenicity tests were performed to fulfill Koch's postulates.

\section{Materials and Methods}

Isolation and morpho-cultural characterization. Isolations were made from 20 symptomatic Stoechas lavender plants with different disease severity. Basal stems and roots were washed with tap water, rinsed in sterile $\mathrm{H}_{2} \mathrm{O}$, and blotted dry with filter paper before being cut into $5-\mathrm{mm}$ pieces. Stem and root pieces were plated onto Phytophthora selective medium PARP (16) in 9-cmdiameter petri dishes ( 5 pieces per dish). Petri dishes were incubated for 5 days at $24 \pm 1{ }^{\circ} \mathrm{C}$ in the dark. Hyphal tips of colonies resembling the morphology of Phytophthora spp. were subcultured on potato dextrose agar (PDA, Oxoid Ltd., Basingstoke, UK) to obtain pure single-hyphae cultures. Isolates were then grown in 9$\mathrm{cm}$-diameter petri dishes containing $20 \mathrm{ml}$ of either PDA or V8A (Campbell V8 juice agar) at $24 \pm 1^{\circ} \mathrm{C}$ for 14 days in darkness to determine the colony morphology. Temperature-growth relationships of isolates were determined by transferring 5-mm-diameter plugs taken from the margins of 7-day-old actively growing colonies at $24 \pm 1^{\circ} \mathrm{C}$ onto both PDA and V8A and incubating at temperatures from 5 to $35^{\circ} \mathrm{C}$ with intervals of $5 \pm 1^{\circ} \mathrm{C}$, in the dark. Colony diameters were measured in two orthogonal directions 5 days after incubation, and the mean daily radial growth rate $(\mathrm{mm} /$ day) at each temperature was calculated. Maximum temper- 
ature for growth was tested between 33 and $36^{\circ} \mathrm{C}$ with $1 \pm 0.2^{\circ} \mathrm{C}$ increments following the method of Brasier et al. (5). Carrot agar (CA) plates started with three 4-mm actively growing mycelial plugs were immediately transferred to the test temperatures, and the extent of mycelial growth was recorded daily for 3 days. Sporangia production was induced by transferring $5-\mathrm{mm}$ plugs of 7-day-old mycelium grown on V8A into petri dishes containing sterile $\mathrm{H}_{2} \mathrm{O}$. Plates were incubated at room temperature (18 to $24^{\circ} \mathrm{C}$ ) for 5 to 10 days under natural light on the bench, and features of sporangia were recorded for each isolate by performing 70 measurements. Similarly, a total of 50 measurements of oogonia, oospores, and antheridia produced on V8A at $24 \pm 1^{\circ} \mathrm{C}$ after 14 days of incubation were made for each isolate. A total of five representative isolates $(953 / 07,956 / 07,957 / 07$, and STLV8 from roots, and STLV11 from stem) were characterized, and each experiment included three replicate dishes per isolate and culture medium. Each experiment was repeated twice. All isolates were deposited at the culture collection of the Department of Agri-food and Environmental Systems Management, Plant Pathology Section, University of Catania.

DNA isolation. Genomic DNA was extracted from two representative isolates (956/07 and 957/07) of the putative hybrid of $P$. nicotianae $\times P$. cactorum recovered from Stoechas lavender. Reference isolates of both putative parental species, i.e., $P$. nicotianae isolate IMI 398853 from blue Mediterranean fan palm (13) and $P$. cactorum isolate IRF14 from oregano, were included in this study. DNA was extracted from mycelium of 7-day-old colonies grown in petri dishes on V8A at $24^{\circ} \mathrm{C}$ by using DNeasy Plant Mini Kit according to the manufacturer's instructions (Qiagen $\mathrm{GmbH}$, Hilden, Germany). DNA concentration and quality were determined using the Quant-it dsDNA BR assay kit and Qubit fluorometer (Invitrogen, Life Technology Corporation, Carlsbad, CA, USA). DNA samples were stored at $-20^{\circ} \mathrm{C}$ before PCR amplification.

ITS-rDNA, coxI, and Pheca sequencing. ITS regions of the rDNA repeat units of isolates were amplified with the universal primers ITS6 and ITS4 according to the protocol described by Cooke et al. (9). Sequencing of the cytochrome c oxidase subunit I (coxI) gene was performed to identify the donor parental species of the mitochondrial genome. Templates of the coxI gene cluster were amplified by using the primers FM 85 and the reverse complement of FM 80 (FM80RC) (25). PCR reactions were done in $25 \mu \mathrm{l}$ and contained $10 \mathrm{ng}$ of DNA, $0.5 \mu \mathrm{M}$ of each primer, $2.5 \mu \mathrm{l}$ of $10 \times$ buffer, $100 \mu \mathrm{M}$ of each dNTP, $2 \mathrm{mM} \mathrm{MgCl}_{2}$, and 1 unit of Taq DNA Polymerase (Invitrogen). Thermocycler parameters were $94^{\circ} \mathrm{C}$ for $2 \mathrm{~min}$, followed by 35 cycles of $94^{\circ} \mathrm{C}$ for $30 \mathrm{~s}, 55^{\circ} \mathrm{C}$ for $30 \mathrm{~s}, 72^{\circ} \mathrm{C}$ for $90 \mathrm{~s}$, with a final extension at $72^{\circ} \mathrm{C}$ for $5 \mathrm{~min}$.

Sequence analysis of a portion of phenol acid decarboxylase (Pheca) gene was performed to establish the allelic state of this gene in the putative $P$. nicotianae $\times$ cactorum hybrid isolates. Specific primers (PhecaF: 5'-GAAGCCGATCATGGTGGT-3' and PhecaR: 5'-TGACCTCCACCTGCTGTACG-3') were designed by aligning available Pheca sequences ( $P$. nicotianae, FJ459730; $P$. cactorum, FJ459731; P. nicotianae $\times$ cactorum, FJ459732 and FJ459733) (15) with ClustalW2 (http://www.ebi.ac.uk/Tools/ $\mathrm{msa}$ /clustalw2/) and chemically synthesized by Invitrogen. Each PCR reaction mix contained $2.5 \mu \mathrm{l}$ of $10 \times$ buffer, $2 \mathrm{mM} \mathrm{MgCl} 2,0.2$ $\mathrm{mM}$ of each dNTP, $0.5 \mu \mathrm{M}$ of each primer, $10 \mathrm{ng}$ DNA template, and PCR grade water to a total volume of $25 \mu$. The PCR thermocycling conditions were as follows: $2 \mathrm{~min}$ at $95^{\circ} \mathrm{C}$, and 35 cycles of $95^{\circ} \mathrm{C}$ for $20 \mathrm{~s}, 60^{\circ} \mathrm{C}$ for $30 \mathrm{~s}, 72^{\circ} \mathrm{C}$ for $45 \mathrm{~s}$, followed by a final extension at $72^{\circ} \mathrm{C}$ for $5 \mathrm{~min}$. The experiment was repeated three times under the same conditions using different DNA extracts.

In all experiments, the presence of PCR products was confirmed by electrophoresis on $1.5 \%$ agarose gel and used directly for sequence determination following treatment with ExoSAP-IT (United States Biochemical, Cleveland). DNA sequencing was performed in both directions from PCR products by BMRGenomics (www.bmr-genomics.it) with the Big Dye Terminator ver. 3.1 (Applera Corporation, Foster City, CA, USA) on a 96capillary Applied Biosystems 3730xl DNA Analyzer.
Species-specific multiplex-PCR and RAPD-PCR assays. Multiplex ITS-PCR assay was performed according to the protocol described by Bonants et al. (4) using the primer pairs NICF1/ NICR2.1 and CACTF1/CACTR1, specific for $P$. nicotianae and $P$. cactorum, respectively. In addition, a different multiplex PCR assay (multiplex PN/PC-PCR) was also performed by using the primer pair PNF/PNR designed by Kong et al. (17) on the basis of $P$. nicotianae-specific sequences of the elicitin gene (parAl), and the SCAR primer pair PC1/PC2 for the detection of $P$. cactorum (7). The multiplex amplifications were carried out in $25-\mu 1$ reaction mixtures as described for Pheca amplification and subjected to thermal cycling $\left(3 \mathrm{~min}\right.$ at $94^{\circ} \mathrm{C}, 35$ cycles of $30 \mathrm{~s}$ at $94^{\circ} \mathrm{C}, 30 \mathrm{~s}$ at $62^{\circ} \mathrm{C}$, and $1 \mathrm{~min}$ at $72^{\circ} \mathrm{C}$, and a final step of $10 \mathrm{~min}$ at $72^{\circ} \mathrm{C}$ ) with a Perkin-Elmer Cetus (Norwalk, CT, USA) Gene Amp PCR System 9600. A negative control using water instead of template DNA was included in all PCR reactions. Amplicons were analyzed by electrophoresis in $1.5 \%$ agarose gel containing SYBR Safe DNA gel stain (Invitrogen) in Tris-acetate-EDTA (TAE) buffer. To confirm the parental origin of the specific PCR products obtained in multiplex ITS-PCR, amplicons were directly sequenced as described above.

For RAPD-PCR, a total of 5 decanucleotide primers (OPB-12, OPB-15, OPB-16, OPE-18, OPE-20) acquired from Operon Technologies Inc. (Alameda, CA, USA) were used. Amplification reactions and post-PCR processes were performed according to the protocol described by Faedda et al. (12).

Pathogenicity tests. Pathogenicity trials were conducted using 6-month-old plants of both Stoechas lavender and English lavender 'Rosea' that is known to be very susceptible to $P$. nicotianae root rot (28). P. nicotianae reference isolates IMI 398853 and TL8VP from lavender (21), one reference isolate of P. cactorum (IRF14), and two representative hybrid isolates (956/07 and 957/07) from Stoechas lavender were tested. Inoculum was produced on a mixture of vermiculite and autoclaved oat seeds (10). Plants were transplanted to pots filled with a mixture of soil (sand/lime/peat $1: 1: 1)$ and $4 \%(\mathrm{vol} / \mathrm{vol})$ inoculum. Control plants were grown in pots containing noninfested soil. After transplanting, all pots were flooded for $24 \mathrm{~h}$ by plugging the drain hole. Plants were grown in a greenhouse at $24 \pm 4^{\circ} \mathrm{C}$. The test was performed twice.

\section{Results}

Morphological and cultural characterization. Isolates with uniform colony morphology were obtained from both basal stems and roots of all the 20 symptomatic Stoechas lavender plants with a mean frequency of 30 and $70 \%$, respectively. On PDA, cultures formed whitish, tender cottony colonies with flattened mycelium and irregular stoloniferous margins. On V8A, colonies showed a chrysanthemum pattern and abundant aerial mycelium (Fig. 1A and B). Optimum growth temperature was $30 \pm 1{ }^{\circ} \mathrm{C}$, and mean $( \pm$ S.D.) radial growth rates of the 5 isolates were $10 \pm 0.5$ and $14 \pm$ $1 \mathrm{~mm} /$ day on PDA and V8A, respectively. The maximum temperature at which continuous growth occurred was $34 \pm 0.2^{\circ} \mathrm{C}$. No growth was observed at 5 and $35^{\circ} \mathrm{C}$.

Colonies developed on V8A were homothallic and produced smooth-walled oogonia measuring $33.3 \pm 2.8 \mu \mathrm{m}$ (mean of five isolates \pm S.D.) in diameter (range 26.9 to $38.5 \mu \mathrm{m}$ ); oospores were aplerotic with a mean diameter of $28.5 \pm 2.1 \mu \mathrm{m}$ (range 22.5 to 34.2 $\mu \mathrm{m})$; antheridia were predominantly amphigynous (Fig. 1E and F). A low proportion of abortive oogonia (less than 20\%) were also observed in all isolates. Sporangia produced in water were subglobose with a prominent papilla, both caducous with a short pedicel ( 2 to $3 \mu \mathrm{m}$ in length) and persistent, sometimes with a lateral insertion in the sporangiophore. The average sporangium size was $46.9 \pm 4.2 \times 36.5 \pm 3.2 \mu \mathrm{m}$, with a mean length-to-width ratio of 1.28 (Fig. 1C and D). Chlamydospores, both terminal and intercalary, were spherical with a diameter ranging from 26.2 to $30.1 \mu \mathrm{m}$.

ITS-rDNA, mitochondrial DNA, and Pheca analyses. PCR amplification of ITS regions from 956/07 and 957/07 isolates resulted in a single band of $831 \mathrm{bp}$. Direct sequencing of this DNA fragment did not reveal any ambiguous nucleotide sites, and 
BLASTn search in GenBank showed that sequences of these isolates were identical to those of several $P$. nicotianae reference isolates (e.g., Accession Nos. GU902246 and HG709173).

PCR reactions of coxI amplified a DNA fragment of the expected size (654 bp) from all Phytophthora isolates examined. The coxI sequences obtained from isolates 956/07 (Accession No. KC109828) and 957/07 (Accession No. KC109829) also showed $100 \%$ identity with sequences of $P$. nicotianae isolates available in GenBank database (e.g., Accession No. GU945494), including the sequence of the isolate IMI 398853 (Accession No. KC109827).

PCR amplification of a portion of Pheca gene of all Phytophthora isolates using primers PhecaF and PhecaR produced DNA fragments of the expected size $(271 \mathrm{bp})$. Consensus sequences of isolates 956/07 (Accession No. KC109825) and 957/07 (Accession No. KC109826) revealed double bases at 12 positions, whereas both $P$. nicotianae IMI 398853 (Accession No. KC109823) and P. cactorum IRF14 (Accession No. KC109824) contained whole sequence with single bases, as expected. Multiple sequence alignment showed 10 identical double bases at the same positions between sequences of isolates from Stoechas lavender and loquat trees (P. nicotianae $\times$ cactorum 95023: Accession No. FJ459732, and LT2852: Accession No. FJ459733) (15). In addition, Stoechas lavender isolates exhibited two additional heterozygous sites at positions 136 and 178 as compared to those of loquat isolates (Table 1). Pheca sequences of $P$. nicotianae IMI 398853 and $P$. cactorum IRF14 were $100 \%$ identical to those of $P$. nicotianae LT215 (FJ459730) and P. cactorum LT198 (FJ459731) isolates available in GenBank (15) (Table 1). In the hybrids examined in this study, all the nucleotide differences were localized at positions wherein the sequences of $P$. nicotianae and $P$. cactorum diverged.

Multiplex and RAPD PCR analyses. Multiplex ITS-PCR using primers specific for $P$. nicotianae (NICF1 and NICR2.1) and $P$. cactorum (CACTF1 and CACTR1) produced a single DNA fragment of the expected size for P. nicotianae IMI 398853 (700 bp) and $P$. cactorum IRF14 (365 bp) reference isolates, while both products were amplified simultaneously for the putative hybrid isolates from Stoechas lavender (Fig. 2). BLASTn analysis in GenBank database showed that the $700 \mathrm{bp}$ and 365 bp consensus sequences were identical to those of $P$. nicotianae and $P$. cactorum, respectively. The alignment between these sequences revealed altogether 7 heterozygous bases only at those positions wherein the 365-bp portion of ITS sequences of $P$. nicotianae and $P$. cactorum diverged (Table 2). Therefore, species-specific ITS-PCR assay followed by sequencing highlighted the coexistence of ITS sequences of both $P$. nicotianae and $P$. cactorum in Stoechas lavender isolates, unlike the direct sequencing of ITS amplicons with universal primers which did not reveal any heterozygous sites. Likewise, in the multiplex PN/PC-PCR experiments with the primer pairs $\mathrm{PNF} / \mathrm{PNR}$ and $\mathrm{PC} 1 / \mathrm{PC} 2$, both isolates from Stoechas lavender showed two bands of $230 \mathrm{bp}$ and $450 \mathrm{bp}$ specific for $P$. nicotianae and $P$. cactorum, respectively. As expected, isolates IMI 398853 of $P$. nicotianae and IRF14 of $P$. cactorum gave a single PCR product of the predicted size for each species (Fig. 3).
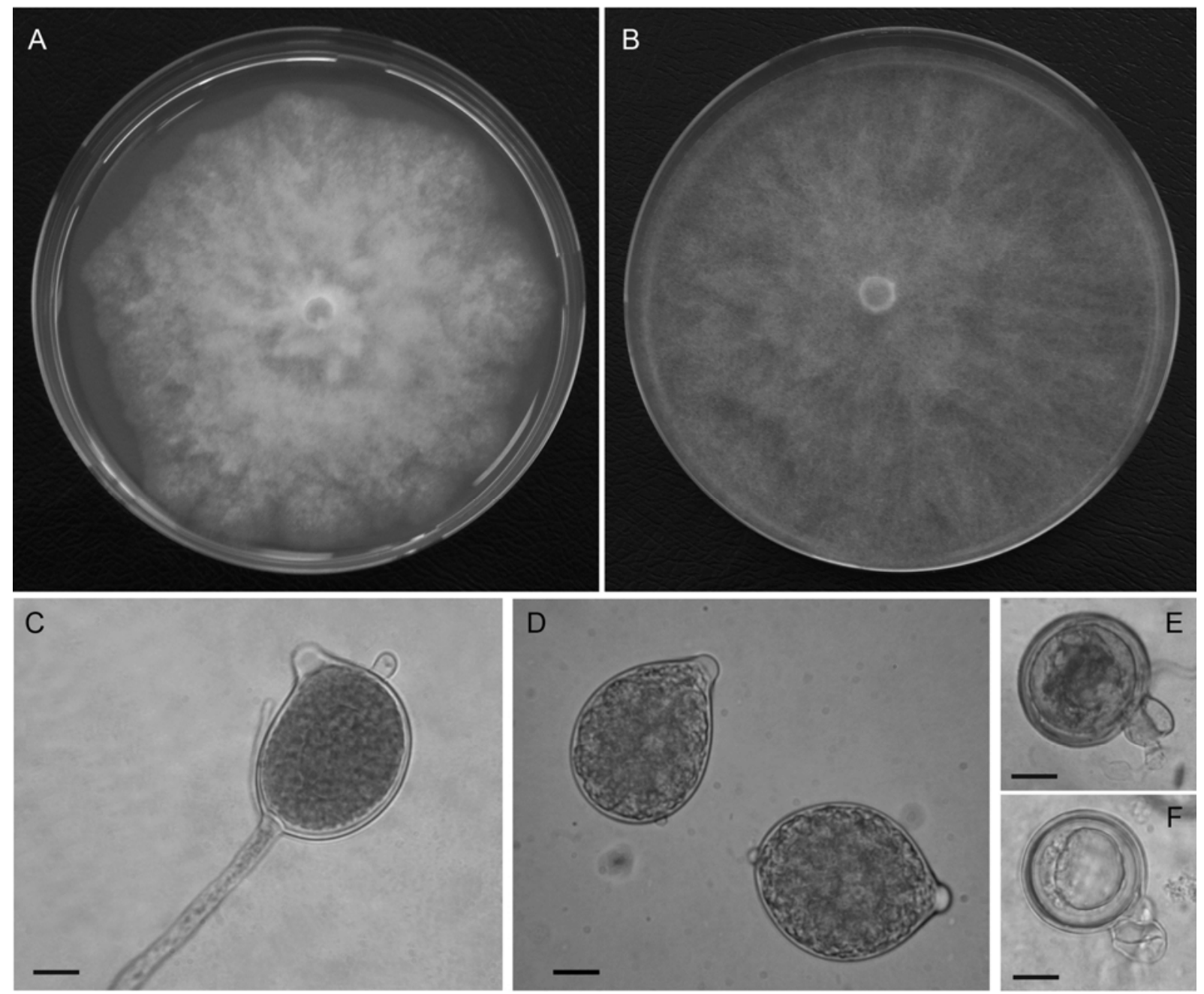

Fig. 1. A and B, Ten-day-old colonies of a Phytophthora x pelgrandis isolate (956/07) from lavender on PDA and V8A, respectively. C, Persistent papillate sporangium of isolate 956/07. Note the unipodial ramification at the base of the intercalary sporangium. D, Subspherical, prominently papillate, caducous sporangia with a short pedicel of isolate 956/07. E and F, Gametangia and oospores of isolate 956/07 produced in a single culture: paragynous and anphigynous antheridia, respectively. Bar in C, D, E, and F represents $10 \mu \mathrm{m}$. 
Highly reproducible RAPD profiles were obtained from isolates with all selected random primers. Three primers out of five generated monomorphic bands specific for each isolate of parental species, and some of these species-specific bands were also observed in the patterns of Stoechas lavender isolates (Fig. 4). These intermediate profiles were compatible with the hybrid origin of isolates from Stoechas lavender with $P$. nicotianae and $P$. cactorum as progenitors.

Pathogenicity tests. Three months after transplanting all plants grown in pots containing soil infested with 956/07 and 957/07 hybrid isolates as well as with IMI 398853 and TL8VP of $P$. nicotianae showed dieback symptoms and extensive root necrosis on both Lavandula species tested. Plants grown in pots containing soil infested with the $P$. cactorum isolate showed no aerial symptoms and only a few necrotic roots, suggesting that this species is weakly pathogenic on lavender. Control plants remained healthy. $P$. nicotianae and $P$. cactorum as well as both hybrid isolates were reisolated solely from roots of inoculated plants. The identity of each species was confirmed by both morphological and cultural characteristics and multiplex PCR analyses with species-specific primers, thus fulfilling the postulates of Koch.

\section{Discussion}

The putative hybrid nature of the Phytophthora isolates recovered from Stoechas lavender in Italy was suspected on the basis of morphological traits, namely the stoloniferous colony morphology on PDA peculiar of $P$. nicotianae and homothallism, which is by contrast atypical for the latter, and was confirmed by the molecular analyses. It could be inferred from DNA analysis that $P$. nicotianae and $P$. cactorum are the parental species of these hybrids, as in their genome the Pheca gene is in a heterozygous condition and each allelic form corresponds to that of these two species. This conclusion is supported by the results of both multiplex and RAPD PCR analyses showing the DNA of the isolates from Stoechas lavender comprised regions from both $P$. nicotianae and $P$. cactorum. Analysis of the coxI gene suggests that these interspecific hybrids inherited the mitochondrial genome from $P$. nicotianae as hitherto has been found in all these hybrids to date $(15,24)$. Both morphological characteristics and sequences of Pheca gene of the Italian hybrid isolates from Stoechas lavender correspond to those of $P$. nicotianae $\times$ cactorum hybrids recovered from $P$. grandiflorum and formally described by Nirenberg et al. (30) as Phytophthora $\times$ pelgrandis. Natural hybrids between $P$. nicotianae and $P$. cactorum were first reported on various ornamental plants, including Lavandula sp., grown in greenhouses in the Netherlands $(4,24)$. Later, two Phytophthora isolates from loquat trees (Eryobotria japonica) collected in central Taiwan in 1995, which were earlier referred to as atypical strains of $P$. nicotianae (8), were identified as hybrids of $P$. nicotianae and $P$. cactorum (22). Conceivably, the homothallic Phytophthora isolates from loquat described by Weltzien and Scwinn (37) in Lebanon were highly likely hybrids of the same species, as their morphological characteristics were very similar to those of isolates from Taiwan. More recently, hybrids originating from P. nicotianae and
$P$. cactorum were recovered from loquat in Peru (2). After natural hybrids of $P$. nicotianae and $P$. cactorum were recovered from $P$. grandiflorum in Germany and formally described as Phytophthora $\times$ pelgrandis (30), they were also reported with the same name in the United States (20) as well as on common box, lavender, and Port-Orford-cedar in different ornamental nurseries in Hungary (35). In this study, Phytophthora $\times$ pelgrandis is reported for the first time in Italy. Phytophthora hybrids generally show numerous abortive oospores, heterozygous profiles for $M d h-2, M d h p$, or $G p i$ isoenzymes, and ITS sequences of both parental species (23); however, in some instances a molecular polyphasic approach is required to ascertain the hybrid nature of the isolates, as direct sequencing of ITS-rDNA does not always reveal intra-isolate heterogeneity. In fact, ITS sequencing of PCR products obtained
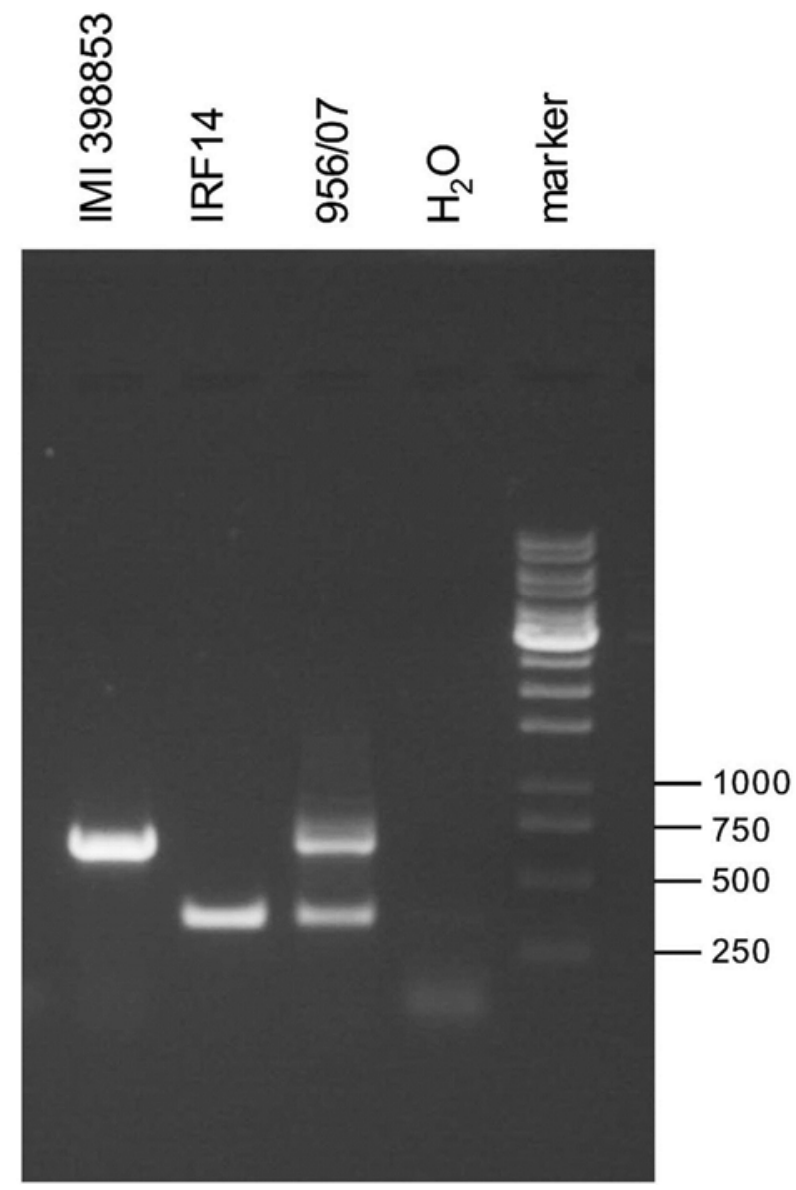

Fig. 2. Internal transcribed spacer (ITS)-rDNA products amplified in multiplex polymerase chain reaction, using primer-pairs NICF1/NICR2.1 and CACTF1/ CACTR1, from Phytophthora nicotiane IMI 398853, P. cactorum IRF14 and one (956/07) of the two putative hybrid isolates from Stoechas lavender. Size of marker bands is indicated in bp.

Table 1. Comparison of variable nucleotide positions identified in a 271-bp fragment of the Phenol acid decarboxylase (Pheca) gene between Phytophthora hybrids and their parental species ${ }^{\mathrm{a}}$

\begin{tabular}{|c|c|c|c|c|c|c|c|c|c|c|c|c|c|c|}
\hline \multirow{2}{*}{$\begin{array}{l}\text { Accession } \\
\text { number }\end{array}$} & \multirow[b]{2}{*}{ Isolate } & \multirow[b]{2}{*}{ Species } & \multicolumn{12}{|c|}{ Nucleotide position } \\
\hline & & & 19 & 34 & 40 & 46 & 49 & 91 & 100 & 136 & 178 & 220 & 229 & 235 \\
\hline KC109825 & $956 / 07$ & P. $\times$ pelgrandis & $\mathrm{R}$ & $\mathrm{R}$ & $\mathrm{R}$ & $\mathrm{R}$ & $S$ & $\mathrm{~S}$ & $S$ & $\mathrm{R}$ & $\mathrm{R}$ & $\mathrm{R}$ & $\mathrm{R}$ & $\mathrm{R}$ \\
\hline KC109826 & $957 / 07$ & P. $\times$ pelgrandis & $\mathrm{R}$ & $\mathrm{R}$ & $\mathrm{R}$ & $\mathrm{R}$ & S & $\mathrm{S}$ & $\mathrm{S}$ & $\mathrm{R}$ & $\mathrm{R}$ & $\mathrm{R}$ & $\mathrm{R}$ & $\mathrm{R}$ \\
\hline FJ459733 & 95023 & P. $\times$ pelgrandis & $\mathrm{R}$ & $\mathrm{R}$ & $\mathrm{R}$ & $\mathrm{R}$ & S & $\mathrm{S}$ & $\mathrm{S}$ & A & A & $\mathrm{R}$ & $\mathrm{R}$ & $\mathrm{R}$ \\
\hline FJ459732 & LT2852 & P. $\times$ pelgrandis & $\mathrm{R}$ & $\mathrm{R}$ & $\mathrm{R}$ & $\mathrm{R}$ & $\mathrm{S}$ & $\mathrm{S}$ & $\mathrm{S}$ & $\mathrm{A}$ & A & $\mathrm{R}$ & $\mathrm{R}$ & $\mathrm{R}$ \\
\hline $\mathrm{KC} 109823$ & IMI 398853 & P. nicotianae & $\mathrm{G}$ & $\mathrm{G}$ & $\mathrm{A}$ & $\mathrm{G}$ & $\mathrm{C}$ & $\mathrm{C}$ & $\mathrm{C}$ & $\mathrm{A}$ & $\mathrm{A}$ & $\mathrm{A}$ & $\mathrm{A}$ & $\mathrm{G}$ \\
\hline FJ459730 & LT215 & P. nicotianae & $\mathrm{G}$ & $\mathrm{G}$ & $\mathrm{A}$ & $\mathrm{G}$ & $\mathrm{C}$ & $\mathrm{C}$ & $\mathrm{C}$ & $\mathrm{A}$ & $\mathrm{A}$ & A & A & $\mathrm{G}$ \\
\hline KC109824 & IRF14 & P. cactorum & $\mathrm{A}$ & $\mathrm{A}$ & $\mathrm{G}$ & A & $\mathrm{G}$ & $\mathrm{G}$ & $\mathrm{G}$ & $\mathrm{G}$ & $\mathrm{G}$ & G & $\mathrm{G}$ & A \\
\hline FJ459731 & LT198 & P. cactorum & $\mathrm{A}$ & $\mathrm{A}$ & $\mathrm{G}$ & A & $\mathrm{G}$ & $\mathrm{G}$ & $\mathrm{G}$ & $\mathrm{G}$ & $\mathrm{G}$ & G & $\mathrm{G}$ & $\mathrm{A}$ \\
\hline
\end{tabular}

${ }^{\mathrm{a}} \mathrm{R}=\mathrm{G} / \mathrm{A} ; \mathrm{S}=\mathrm{C} / \mathrm{G}$. Pheca sequences FJ459733, FJ459732, FJ459730, and FJ459731 deposited in GenBank by Hurtado-Gonzales et al. (15) were used as references. 
with universal primers ITS6 and ITS4 failed to discriminate the Stoechas lavender isolates of $P . \times$ pelgrandis from $P$. nicotianae in this study, and similar results were already reported by Nirenberg et al. (30) for P grandiflorum hybrids from Germany. However, amplification of ITS region with specific primer pairs NICF1/ NICR2.1 and CACTF1/CACTR1 revealed the heterozygous condition of this region in the lavender Stoechas isolates. The inability of generic primers to reveal the heterozygosity within the ITSrDNA with direct sequencing may be explained assuming that they contain a number of copies from the parental $P$. nicotianae species larger than those of the other donor species. Moreover, it can be supposed that the high proportion of G-C in $P$. cactorum ITS sequences might have favored the amplification of the allele of the other parental species $P$. nicotianae as demonstrated by Walsh et al. (36) for other genes in humans. The heterozygous condition of ITS regions in lavender Stoechas isolates was confirmed by the multiplex ITS-PCR assay. Likewise, multiplex PN/PC-PCR provides an additional molecular tool to further demonstrate the hybrid nature of the Italian Stoechas lavender isolates. Interestingly, the nucleotide differences at two positions in the sequence of the Pheca gene between Italian isolates from Stoechas lavender and isolates from loquat trees found in Taiwan and Peru (2) suggest these hybrids originated from independent hybridization events involving parental species with intraspecific mutations.

Like the parental species $P$. nicotianae, $P . \times$ pelgrandis seems a quite common pathogen of lavender, as it was recovered from lavender plants affected by root rot and basal stem necrosis in ornamental nurseries in several European countries, including the Netherlands (4), Hungary (35), and now Italy. By contrast, $P$. cactorum, the other parental species, is an occasional and weak root pathogen on this host. Pathogenicity tests indicate that natural hybrids of these two species are as aggressive as the parental $P$. nicotianae, from which they also inherited other ecological traits, such as a high optimum temperature and partly amphigynous antheridia and noncaducous sporangia. Conversely, these hybrids share with $P$. cactorum homothallism, partly paragynous antheridia and sporangium caducity. It can be hypothesized that this novel combination of biological and ecological characteristics may improve the fitness of the interspecific hybrids of $P$. nicotianae and $P$. cactorum and their adaptability to the environmental conditions in nurseries of ornamentals. A high optimum temperature, comparable to the optimum of the thermophilic parental species $P$. nicotianae, conceivably favors their activity in the greenhouse and during summer months, while a minimum temperature higher than the minimum of some isolates of $P$. nicotianae (30) may be conducive to early infections in late winter, thus widening the favorable period for the infections by hybrids. In addition, these hybrids can produce resting structures such as chlamydospores that allow them to survive during winter or dry periods in soil or within infected host tissues. Moreover, the rapid spread of these hybrids in nurseries is favored by the production of caducous sporangia which are disseminated more easily than persistent sporangia by irrigation water. So far, only natural hybrids of a few Phytophthora species have been identified and described (19,23). Recently, Phytophthora andina has also been identified as a natural hybrid of $P$. infestans and a hitherto unknown other parent (14). The wide diffusion of natural hybrids of $P$. nicotianae and $P$. cactorum and the differences in the sequences of the Pheca gene between isolates, recovered from Stoechas lavender in Italy and isolates from loquat trees found in Taiwan and Peru, indicate that breeding events between these two Phytophthora species occur frequently, even though $P$. nicotianae and $P$. cactorum are in different ITS subclades $(3,9,18)$, thus suggesting a higher affinity than inferred on the basis of ITS sequences alone. Both parents evolved allopatric and hence may not have developed premating barriers. By contrast, it can be supposed that the close similarity between $P . \times$ pelgrandis isolates recovered from lavender in Hungary, Italy, and the Netherlands would suggest these hybrids propagate clonally and are spreading in nursery ornamentals through global trade following commercial routes. Horticultural centers are known to be the main propagators of pathogen dispersion (26). High-resolution whole genome DNA profiling analysis (e.g., AFLP or microsatellites) would be required to determine whether the lavender strains are really identical. As demonstrated by AFLP analysis, the three hybrid strains from lavender in the Netherlands originated from at least two independent hybridization events (4). The diffusion of $P . \times$ pelgrandis pathogenic isolates in cultivations of lavender could exacerbate the damage caused by Phytophthora root and collar rot whose main causal agent in Europe presently is P. nicotianae, one of the parental strains of these hybrids. Hygienic measures such as presymp-

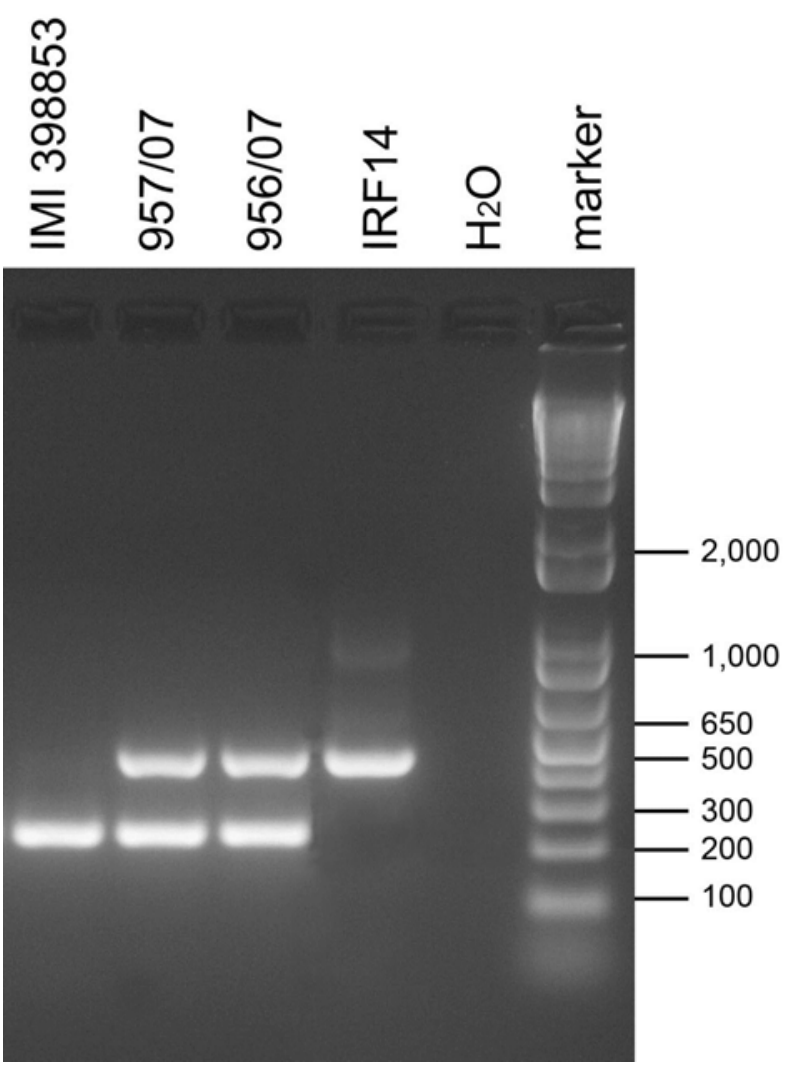

Fig. 3. Multiplex polymerase chain reaction with primer pairs PNF/PNR and PC1/ PC2 specific for Phytophthora nicotianae and P. cactorum, respectively, of DNA from $P$. nicotianae IMI 398853, P. cactorum IRF14, and putative hybrid isolates 957/07 and $956 / 07$ from Stoechas lavender. Size of marker bands is indicated in bp.

Table 2. Comparison of variable nucleotide positions identified in a 365-bp fragment of the ITS1-5.8S-ITS2 regions between Phytophthora hybrids and their parental species $^{\mathrm{a}}$

\begin{tabular}{|c|c|c|c|c|c|c|c|c|}
\hline \multirow[b]{2}{*}{ Isolate } & \multirow[b]{2}{*}{ Species } & \multicolumn{7}{|c|}{ Nucleotide position } \\
\hline & & 1 & 15 & 27 & 47 & 48 & 55 & 363 \\
\hline $956 / 07$ & $P . \times$ pelgrandis & $\mathrm{R}$ & W & $\mathrm{R}$ & $\mathrm{K}$ & $\mathrm{Y}$ & $\mathrm{Y}$ & $\mathrm{Y}$ \\
\hline $957 / 07$ & P. $\times$ pelgrandis & $\mathrm{R}$ & W & $\mathrm{R}$ & $\mathrm{K}$ & $\mathrm{Y}$ & $\mathrm{Y}$ & $\mathrm{Y}$ \\
\hline IMI 398853 & P. nicotianae & A & A & A & $\mathrm{T}$ & $\mathrm{T}$ & $\mathrm{T}$ & $\mathrm{C}$ \\
\hline IRF14 & P. cactorum & $\mathrm{G}$ & $\mathrm{T}$ & G & $\mathrm{G}$ & $\mathrm{C}$ & $\mathrm{C}$ & $\mathrm{T}$ \\
\hline
\end{tabular}

${ }^{\mathrm{a}} \mathrm{R}=\mathrm{G} / \mathrm{A} ; \mathrm{W}=\mathrm{A} / \mathrm{T} ; \mathrm{K}=\mathrm{G} / \mathrm{T} ; \mathrm{Y}=\mathrm{C} / \mathrm{T}$. 


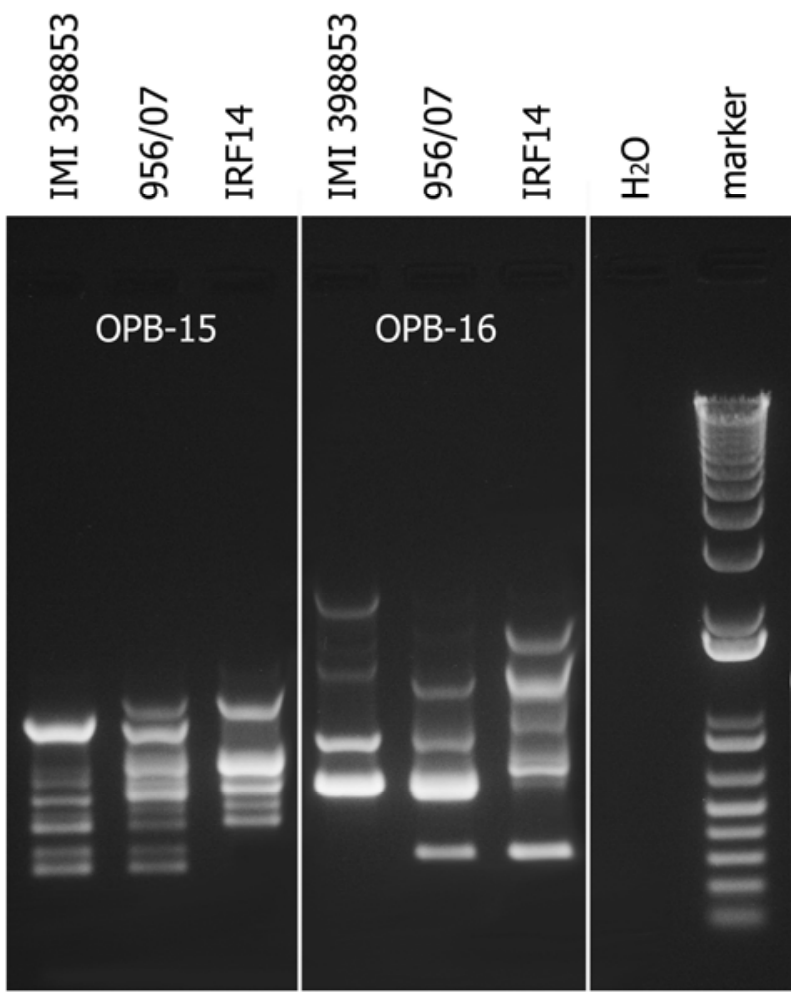

Fig. 4. Random amplified polymorphic DNA profiles of Phytophthora nicotianae IMI 398853 , P. cactorum IRF14, and one putative hybrid isolate 956/07 from Stoechas lavender obtained using two universal decamer primers OPB-15 and OPB-16.

tomatic testing of plants may reduce the proliferation and spread of the Phytophthora hybrids.

\section{Acknowledgments}

This work was partially funded by MIUR-FIRB 2010 "Metagenomic strategies to assess genetic diversity in soil-borne Phytophthora species", MIUR-PRIN 2008 "Emerging diseases caused by soil-borne pathogens: molecular monitoring of nurseries of ornamental plants and control strategies", OTKA grant K101914, and by University of Catania-PRA 2009 "Genetic characterization of soil-borne populations of Phytophthora species as causal agents of root and collar rots of ornamentals in nurseries".

\section{Literature Cited}

1. Álvarez, L. A., Pérez-Sierra, A., Armengol, J., and García-Jiménez, J. 2007. Characterization of Phytophthora nicotianae isolates causing collar and root rot of lavender and rosemary in Spain. J. Plant Pathol. 89:261-264.

2. Aragon-Caballero, L. M., Hurtado-Gonzales, O. P., Flores-Torres, J. G., Figueroa, C., and Lamour, K. H. 2006. Root rot of loquat (Eriobotrya japonica [Thunb.] Lindl.) caused by Phytophthora species. Fitopatologia 41:25-33.

3. Blair, J. E., Coffey, M. D., Park, S.-Y., Geiser, D. M., and Kang, S. 2008. A multi-locus phylogeny for Phytophthora utilizing markers derived from complete genome sequences. Fungal Genet. Biol. 45:266-277.

4. Bonants, P. J. M., Hagenaar-de Weerdt, M., Man in't Veld, W., and Baayen, R. P. 2000. Molecular characterization of natural hybrids of Phytophthora nicotianae and P. cactorum. Phytopathology 90:867-874.

5. Brasier, C. M., Cooke, D. E., Duncan, J. M., and Hansen, E. M. 2003. Multiple new phenotypic taxa from trees and riparian ecosystems in Phytophthora gonapodyides-P. megasperma ITS Clade 6, which tend to be high-temperature tolerant and either inbreeding or sterile. Mycol. Res. 107:277-290.

6. Cacciola, S. O., Williams, N. A., Cooke, D. E. L., and Duncan, J. M. 2001. Molecular identification and detection of Phytophthora species on some important Mediterranean plants including sweet chestnut. For. Snow Landsc. Res. 76:351-356.

7. Causin, R., Scopel, C., Grendene, A., and Montecchio, L. 2005. An improved method for the detection of Phytophthora cactorum (L.C.) Schröeter in infected plant tissues using SCAR markers. J. Plant Pathol. 87:25-35.

8. Chern, L. L., Ann, P. J., and Young, H. R. 1998. Root and foot rot of loquat in Taiwan caused by Phytophthora. Plant Dis. 82:651-656.

9. Cooke, D. E. L., Drenth, A., Duncan, J. M., Wagels, G., and Brasier, C. M. 2000. A molecular phylogeny of Phytophthora and related oomycetes. Fungal Genet. Biol. 30:17-32
10. Davino, S., Cacciola, S. O., Pennisi, A. M., and Li Destri Nicosia, M. G. 2002. Phytophthora palmivora a new pathogen of lavender in Italy. Plant Dis. 86:561.

11. Dervis, S., Arslan, M., Serce, C. U., Soylu, S., and Uremis, I. 2011. First report of a root rot caused by Phytophthora palmivora on Lavandula angustifolia in Turkey. Plant Dis. 95:1035.

12. Faedda, R., Agosteo, G. E., Schena, L., Mosca, S., Frisullo, S., Magnano di San Lio, G., and Cacciola, S. O. 2011. Colletotrichum clavatum sp. nov. identified as the causal agent of olive anthracnose in Italy. Phytopathol Mediterr. 50:283-302.

13. Faedda, R., Pane, A., Granata, G., and Magnano di San Lio, G. 2011. First report of Phytophthora nicotianae as pathogen of blue Mediterranean fan palm. New Dis. Rep. 23:3 http://dx.doi.org/10.5197/j.2044-0588.2011. 023.003

14. Goss, E. M., Cardenas, M. E., Myers, K., Forbes, G. A., Fry, W. E., Restrepo, S., and Grünwald, N. J. 2011. The plant pathogen Phytophthora andina emerged via hybridization of an unknown Phytophthora species and the Irish potato famine pathogen, P. infestans. PLoS One 6:e24543 http:// dx.doi.org/10.1371/journal.pone. 0024543

15. Hurtado-Gonzales, O. P., Aragon-Caballero, L. M., Flores-Torres, J. G. Man in't Veld, W., and Lamour, K. H. 2009. Molecular comparison of natural hybrids of Phytophthora nicotianae and P. cactorum infecting loquat trees in Peru and Taiwan. Mycologia 101:496-502.

16. Jeffers, S. N., and Martin, S. B. 1986. Comparison of two media selective for Phytophthora and Pythium species. Plant Dis. 70:1038-1043.

17. Kong, P., Hong, C., Jeffers, S. N., and Richardson, P. A. 2003. A speciesspecific polymerase chain reaction assay for rapid detection of Phytophthora nicotianae in irrigation water. Phytopathology 93:822-831.

18. Kroon, L. P. N. M., Bakker, F. T., Van den Bosch, G. B. M., Bonants, P. J. M., and Flier, W. G. 2004. Phylogenetic analysis of Phytophthora species based on mitochondrial and nuclear DNA sequences. Fungal Genet. Biol. 41:766-782.

19. Kroon, L. P. N. M., Brouwer, H., de Cock, A. W. A. M., and Govers, F 2012. The genus Phytophthora anno 2012. Phytopathology 102:348-364.

20. Leonberger, A. J. 2010. Distribution and host specificity of Phytophthora species found in Indiana nurseries, greenhouses and landscape plantings. Ph.D. thesis. Pages 1-70. Purdue University Press, Lafayette, IN.

21. Mammella, M. A., Cacciola, S. O., Martin, F., and Schena, L. 2011. Genetic characterization of Phytophthora nicotianae by the analysis of polymorphic regions of the mitochondrial DNA. Fungal Biol. 115:432-442.

22. Man in't Veld, W. A. 2001. First report of natural hybrids of Phytophthora nicotianae and P. cactorum on loquat in Taiwan. Plant Dis. 85:98.

23. Man in't Veld, W. A., Rosendahl, K. C. H. M., and Hong, C. 2012. Phytophthora $\times$ serendipita $\mathrm{sp}$. nov. and $P . \times$ pelgrandis, two destructive pathogen generated by natural hybridization. Mycologia 104:1390-1396.

24. Man in't Veld, W. A., Veenbaas-Rijks, W. J., Ilieva, E., de Cock, A. W. A M., Bonants, P. J. M., and Pieters, R. 1998. Natural hybrids of Phytophthora nicotianae and $P$. cactorum demonstrated by isozyme analysis and random amplified polymorphic DNA. Phytopathology 88:922-929.

25. Martin, F. N., and Tooley, P. W. 2003. Phylogenetic relationships among Phytophthora species inferred from sequence analysis of mitochondrially encoded cytochrome oxidase I and II genes. Mycologia 95:269-284.

26. Mascheretti, S., Croucher, P. J. P., Kozanitas, M., Baker, L., and Garbelotto, M. 2009. Genetic epidemiology of the Sudden Oak Death pathogen Phytophthora ramorum in California. Mol. Ecol. 18:4577-4599.

27. Minuto, A., Minuto, G., and Garibaldi, A. 1999. Phytophthora nicotianae var. parasitica, nuovo parassita della lavanda allevata in vaso. Colture Protette 28:43-45.

28. Minuto, G., Armato, B., Gilardi, G., and Garibaldi, A. 2001. Prime osservazioni sulla suscettibilità a Phytophthora nicotianae var. parasitica di selezioni di lavanda. Inform. Fitopatol. 51:69-72.

29. Nakova, M. 2011. Phytosanitary monitoring of lavender diseases. Agrarni Nauki 3:5-10

30. Nirenberg, H. I., Gerlach, W. F., and Gräfenhan, T. 2009. Phytophthora $\times$ pelgrandis, a new natural hybrid pathogenic to Pelargonium grandiflorum hort. Mycologia 101:220-231.

31. Orlikowski, L. B., and Valjuskaite, A. 2007. New record of Phytophthora root and stem rot of Lavendula angustifolia. Acta Mycol. 42:193-198.

32. Paez, J. I., Berra, D., Vega, J. M., and Tello, J. 1993. Identification de Phytophthora palmivora Butler en jardines de la Exposicion Universal de Sevilla. Bol. de Sanidaad Vegetal. Plagas 19:633-647.

33. Pappas, A. 1978. New diseases caused by Phytophthora spp. Phytophthora Newsl. 6:72-73.

34. Putnam, M. 1991. Root rot of lavender caused by Phytophthora nicotianae. Plant Pathol. 40:480-482.

35. Szigethy, A., Nagy, Z. Á., Vettraino, A. M., Józsa, A., Cacciola, S. O., Faedda, R., and Bakonyi, J. 2012. First report of Phytophthora $\times$ pelgrandis causing root rot and lower stem necrosis of common box, lavender and Port-Orford-cedar in Hungary. Plant Dis. http://dx.doi.org/10.1094/PDIS07-12-0662-PDN

36. Walsh, P. S., Erlich, H. A., and Higuchi, R. 1992. Preferential PCR amplification of alleles: Mechanisms and solutions. Genome Res. 1:241-250.

37. Weltzien, H. C., and Scwinn, F. J. 1966. Phytophthora trunk rot on loquat trees, Eriobotrya japonica, in Lebanon. Phytopathol. Z. 56:331-339. 